\title{
Effects of Sub-lethal Exposure of Lead Acetate on Histopathology of Gills, Liver, Kidney and Muscle and its Accumulation in these Organs of Clarias gariepinus
}

\author{
Hmoud Fares Alkahem Al-Balawi, Ali Sulaiman Al-Akel, Fahad Al-Misned, El Amin \\ Mohamed Suliman, Khalid Abdullah Al-Ghanim, Shahid Mahboob and Zubair Ahmad* \\ Department of Zoology; College of Science; King Saud University; P.B. 2455, Riyadh - 11451; Saudi Arabia
}

\begin{abstract}
The aim of this work was to study the effects of sub-lethal exposure of lead acetate on the histopathology of the gills, liver, kidney and muscle and its accumulation in these organs of Clarias gariepinus. Results showed that lead accumulation in the tissues of $C$. gariepinus was dependent on the exposure period and lead concentration. Gills and liver were the predominant storage tissue and the order of accumulation in tissues was gill > liver > kidney > muscle. Some structural changes were observed in different organs, especially in the gills of the fishes exposed to lead acetate. Epithelial hypertrophy and epithelial lifting were apparent in the gills of exposed fishes. The degeneration of cytoplasm and secondary lamellae was also observed. Necrosis of hepatocytes was apparent. Glomerular expansion and gaps between the muscular bundles were found in the fishes exposed to lead acetate.
\end{abstract}

Key words: Clarias gariepinus; lead acetate; accumulation; histopathology

\section{INTRODUCTION}

Lead has the potential to adversely affect the human and animal health. It causes physiological, biochemical, and neurological dysfunctions in humans (Nordberg et al. 2007). Mobarak (2008) reported that low level of lead exposure during the early development produced long-lasting cognitive and neurobehavioural deficit, persistent immune changes, reduced fertility, a delay in sexual maturity, irregular estrus and reduced number of corpora lutea in human and experimental animals. Notable and recent reports have indicated that lead can cause neurological, gastrointestinal, reproductive, circulatory, immunological, histopathological and histochemical disorders in the animals (Park et al. 2006; Berrahal et al. 2007; Reglero et al. 2009; Abdallah et al. 2010; Mobarak and Sharaf 2011). Fishes accumulate lead from the polluted environments and the metal is then distributed in their tissues. Lead accumulation among the tissues varies depending on the source, food or waterborne (Sorensen 1991). Whatever be the exposure route, lead gets accumulated significantly higher in the gills, liver and kidneys (Sivaprasad et al. 2004). Because fishes are an important food resource and a major aquatic ecosystem component, it is important to assess the adverse effects of lead on fishes.

Bioaccumulation patterns of metals in fish tissues can be utilized as effective indicator of environmental contamination of metal (Larsson et al. 1985). Moreover, tissue-specific accumulation of metals was proposed as a key indicator of chronic exposure (Bergman and Dorward-King 1997). Thus, the kinetics of lead accumulation in

*Author for correspondence: Zahmed@ksu.edu.sa 
fish tissues is of great importance. Lead acetate and mercuric chloride have genotoxic and cytotoxic damage in the gills and fin epithelial cells of Auratue auratus (Cavas 2007). The optimum limits for lead in the food of animal origin ranges from $0.01-1.00 \mathrm{mg} / \mathrm{kg}$. Dietary uptake of metals is a major cause of long-term contamination in wild fish (Dallinger et al. 1987), and there is a renewed interest in the nutritional and toxicological effects of metals in the food of fish (Handy 1996). Heavy metals are an important class of pollutants with both lethal and sub-lethal effects on the organisms. The latter are receiving increased attention, as these may produce harmful ecological outcomes (Boyd 2010).

C. gariepinus is an economically important freshwater, commonly cultured fish in Saudi Arabia, but little information is available on the effects of lead, particularly through the sub-lethal exposure on its metabolic activities. Therefore, the aim of this study was to investigate lead accumulation in $C$. gariepinus through the sublethal exposure and effects on the histopathological alteration in liver, kidney, gills and muscle tissues.

\section{MATERIALS AND METHODS}

The healthy and active specimens of C. gariepinus (total body weight 50-60 g and total length 21-23 $\mathrm{cm})$ were obtained from a fish farm run by King Abdul Aziz City for Science and Technology (KACST), Kingdom of Saudi Arabia and acclimated to lab conditions in big tanks for one month. Fishes were fed a lead-free diet at a rate of $3 \%$ body weight daily (as two meals, $1.5 \%$ bw/day). After one month of acclimation, fishes were randomly transferred to small fish aquaria. Then the fishes were exposed to three different concentrations $\left(5,10\right.$, and $20 \%$ of the $\mathrm{LC}_{50}$ which was equivalent to $6.1,12.2$ and $24.4 \mathrm{mg} / \mathrm{l}$, respectively) of lead acetate (Mol. Wt. 325.29). A control set was also run for the comparison. Each of the four groups of $C$. gariepinus was fed a commercial fish food, $3 \%$ of the body weight for six weeks. The experiment was run with three replicates. The experimental fishes were maintained and tested under a $12 \mathrm{~h}$ light/dark cycle $(06-18 \mathrm{~h})$. Water quality was measured after every three days during the experimental periods (Table $1)$.

Table 1 - Water chemistry of tanks during the experimentation period.

\begin{tabular}{lll}
\hline Parameters & Average & $\mathbf{\pm S D}$ \\
\hline Temparature $\left({ }^{\circ} \mathrm{C}\right)$ & 26.53 & 0.8 \\
Dissolved Oxygen $(\mathrm{mg} / \mathrm{l})$ & 4.9 & 0.5 \\
PH & 7.3 & 0.5 \\
Hardness $(\mathrm{mg} / \mathrm{l})$ & 210 & 3.20 \\
TDS $(\mathrm{ppm})$ & 550 & 3.27 \\
\hline
\end{tabular}

\section{Lead Analysis}

Fishes were not fed $24 \mathrm{~h}$ prior to sampling to allow all feed to be excreted. They were sampled after every two weeks to determine lead concentration in the gills, kidney, liver and muscle. Five fishes were removed from each test concentration and control. Tissue samples were dried at $75{ }^{\circ} \mathrm{C}$ and kept in desiccators until digestion. Known weight of dry tissue was kept in muffle furnace at $550{ }^{\circ} \mathrm{C}$ for $8 \mathrm{~h}$, and then cooled to room temperature. Then $2 \mathrm{ml}$ of concentrated $\mathrm{HNO}_{3}$ was added to each sample and heated on a heating plate till dry. The samples were again kept in muffle furnace at $550^{\circ} \mathrm{C}$ for one hour, cooled to room temperature, dissolved in $10 \mathrm{ml}$ of $1 \mathrm{~N} \mathrm{HCl}$ and filtered. The clean samples were used to quantify the lead using atomic absorption spectrophotometer. Lead concentration of tissues was expressed as $\mu \mathrm{g} / \mathrm{g}$ dry weight.

\section{Histochemistry}

At the end of exposure period, the fishes were sacrificed and the liver, gills, kidney and muscle were excised. They were rinsed with physiological saline $(0.75 \% \mathrm{NaCl})$ to remove the blood and to clean the mucus attached to the tissues. The tissues were then fixed in SUSA for $24 \mathrm{~h}$, sectioned and stained by standard methods. The main steps involved were dehydration, clearing, and infiltration, embedding, sectioning and staining. Haematoxylin was used for staining of the various tissues. 


\section{RESULTS}

The accumulation of lead in the gill, kidney, liver and muscle of $C$. gariepinus, as a function of exposure time and concentration are shown in Figures 1-4. In the first two weeks, lead accumulation in different organs did not vary significantly. After six weeks of exposure, lead accumulation increased and seemed to depend upon the lead concentration (Figures 1-4). Lead concentration increased sharply reaching two to four folds higher in the treated groups (12.2 and $24.4 \mathrm{mg} / \mathrm{l}$ ) compared to the control. The concentrations in the kidney were approximately an order of magnitude lower than for the liver and gills, and increased significantly $(\mathrm{p}<0.05)$ after four and six weeks in higher concentrations (12.2 and $24.4 \mathrm{mg} / \mathrm{l}$ ) of exposure. Lead concentration in liver increased significantly $(\mathrm{P}<0.05)$ with time and level of concentration (Figures 1-4). During the first two weeks, the level of lead increased to $49.84 \mu \mathrm{g} / \mathrm{g}$ (a four-folds increase as compared to the control) at $24.4 \mathrm{mg} / \mathrm{l}$ dose. Lead concentration increased significantly $(\mathrm{P}<0.05)$ after the four week at all concentrations tested. Finally, after six weeks, lead concentrations in the liver were increased about seven-folds compared to the control in all the treatments. Low lead accumulation was observed in the muscles. After six weeks lead exposure to the fishes, the order of lead accumulation was in the gills $>$ liver $>$ kidney $>$ muscles.

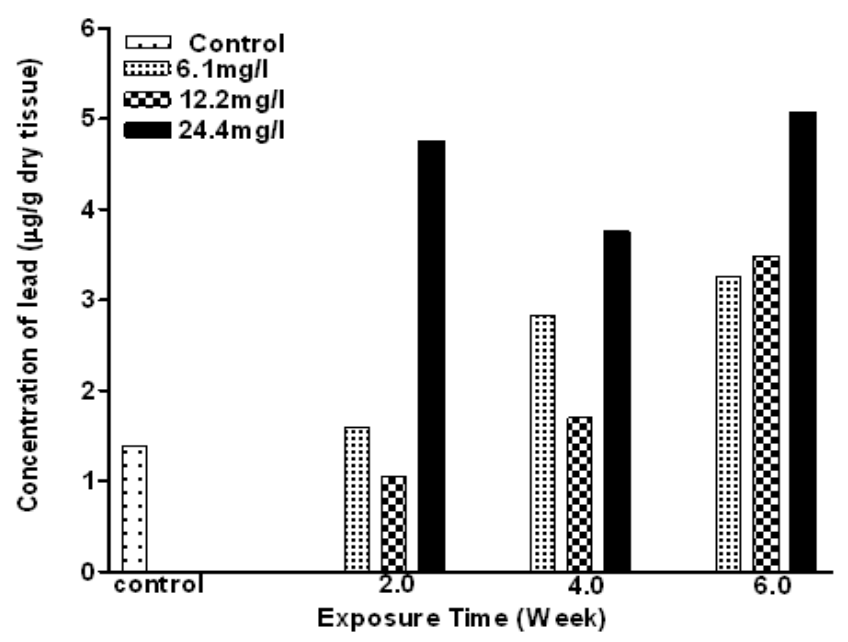

Figure 1 - Concentration of lead in the muscle of exposed Clarias gariepinus

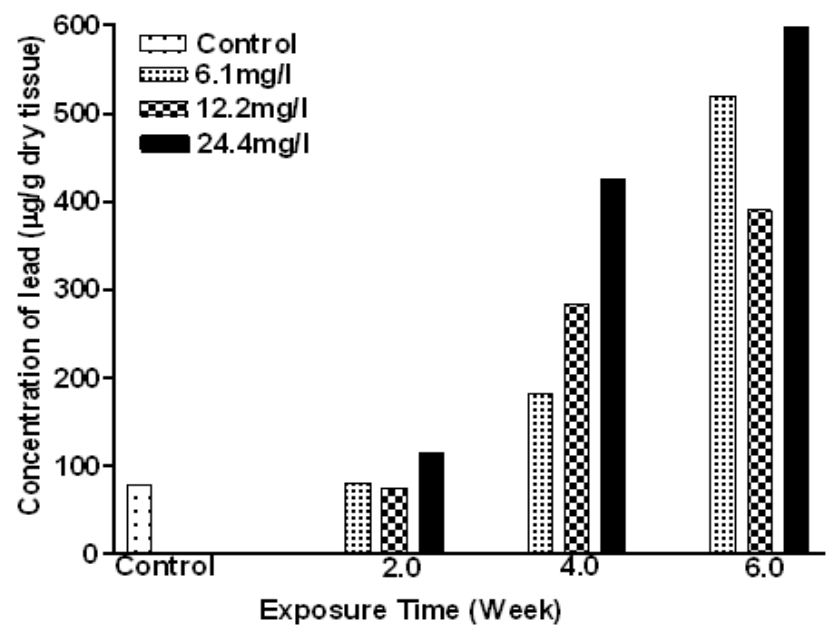

Figure 2 - Concentration of lead in gills of exposed Clarias gariepinus 


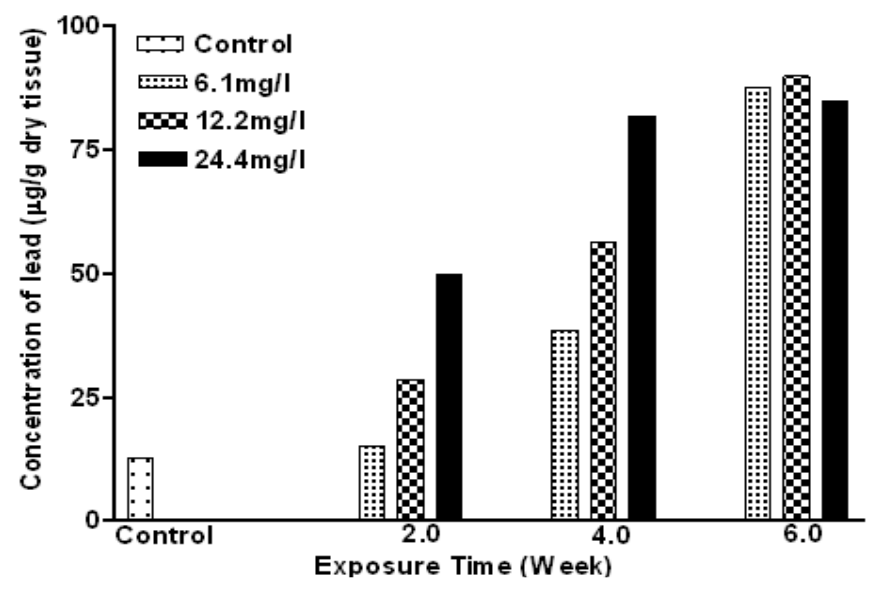

Figure 3 - Concentration of lead in the liver of exposed Clarias gariepinus

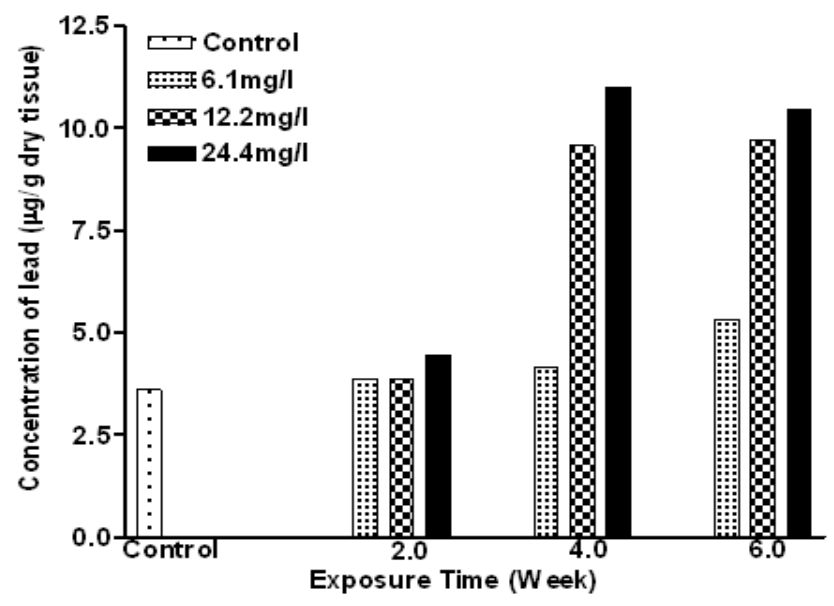

Figure 4 - Concentration of lead in kidney of exposed Clarias gariepinus

Figures 5-8; C, T1, T2 and T3 show the control and lead acetate exposure of the fishes at the concentration of $6.1 \mathrm{mg} / \mathrm{L}, 12.2 \mathrm{mg} / \mathrm{L}$ and 24.4 $\mathrm{mg} / \mathrm{L}$, respectively. There were some cases of blood congestion found in C. gariepinus gills (T1T3), epithelial hypertrophy, epithelial lifting (T1T3), vacuolar degeneration of the cytoplasm and degeneration of secondary lamella were also observed (T3). The main alterations found in the liver of C. gariepinus (Fig. 6) were vacuolar degeneration of the cytoplasm ( $\mathrm{T} 1$ and $\mathrm{T} 3$ ), hyaline degeneration (T1), necrosis of hepatocyte nucleus (T2 and T3), hepatocytes with double nuclei (T3). The alterations found in the kidney are shown in Figure 7. The most important change was found in the glomerulus of $C$. gariepinus. There was glomerular expansion, resulting in the reduction of Bowman's space (T1 and $\mathrm{T} 2$ ). In the tubules, the most frequent alterations were tubular necrosis (T2 and T3) and blood congestion (T3). The main alteration in $C$. gariepinus muscles found (Fig. 8) was gaps between the muscular bundles (T1-T3). 

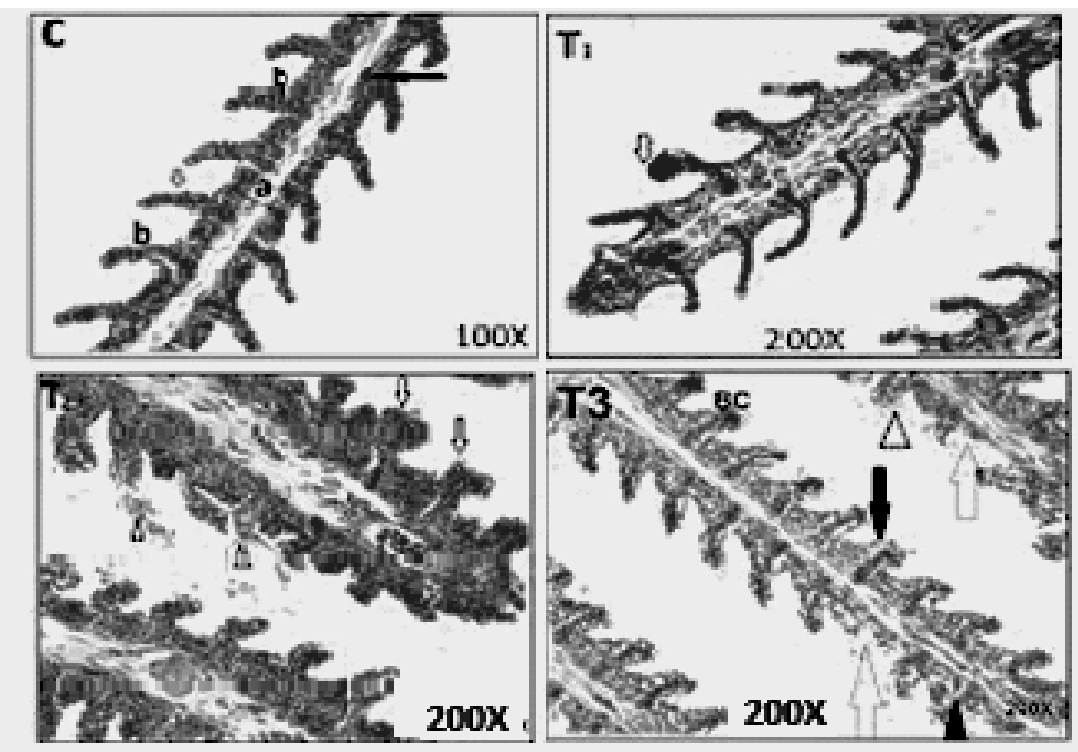

Figure 5 - Gill tissue of C. gariepinus (C) Control, HandE 100X - Primary lamellae(a), secondary lamellae(b), epithelial cell (white arrow), Red blood cell (black arrow). (T1) Exposed to $6.1 \mathrm{mg}$, HandE 200X- Blood congestion (white arrow). (T2) Exposed to $12.2 \mathrm{mg}$ HandE 200X- epithelial hypertrophy (white arrows), epithelial lifting (arrow head), Blood congestion (BC). (T3) Exposed to $24.4 \mathrm{mg}, 200 \mathrm{X}$ - epithelial hypertrophy (black arrows), epithelial lifting arrow head), blood congestion (BC), vacuolar degeneration of cytoplasm (V), degeneration of secondary lamellae (white arrows).

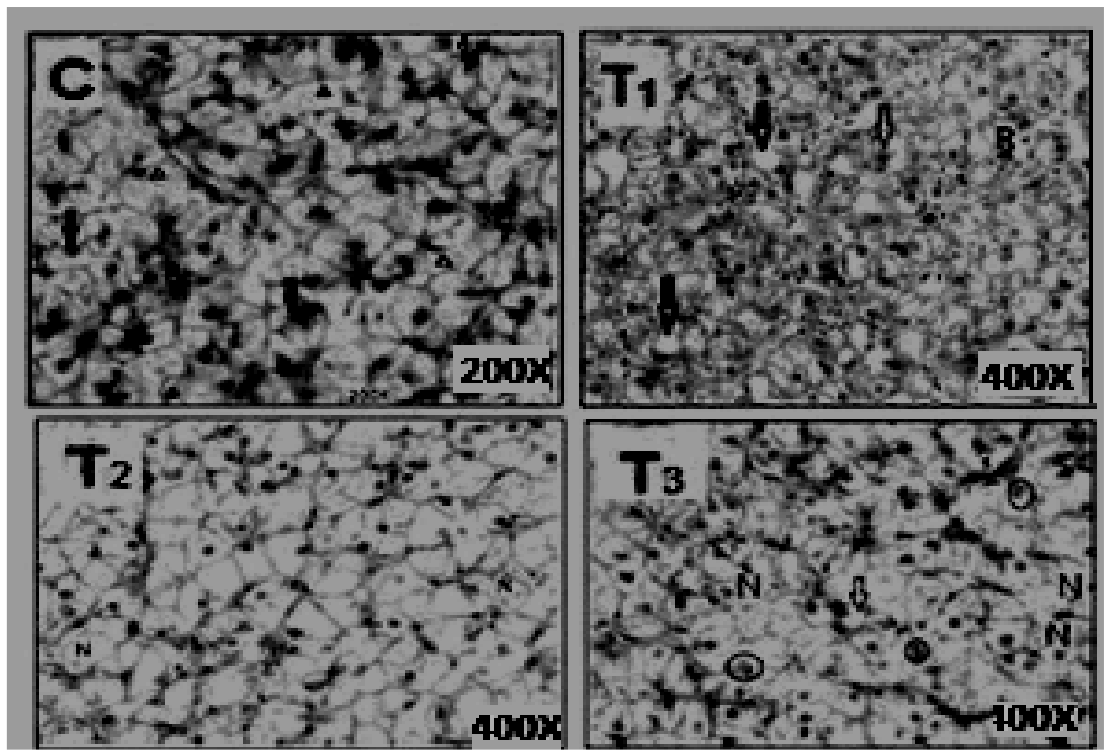

Figure 6 - Liver tissue of C. gariepinus (C) Control, HandE 200X - Hepatocyte (black arrow) glycogen fibers (arrow heads), red blood cell (white arrow). (T1) Exposed to $6.1 \mathrm{mg}$, HandE 400X - Vacuolar degeneration of cytoplasm (V), hyaline degeneration (black arrow), Red blood cells (R). (T2) Exposed to 12.2mg, HandE 400X -Necrosis of hepatocyte nucleus (N). (T3) Exposed to $24.4 \mathrm{mg}$, HandE 400X- Double nucleolus hepatocyte (circle), Necrosis of hepatocyte nucleus $(\mathrm{N})$, Vacuolar degeneration (white arrow). 


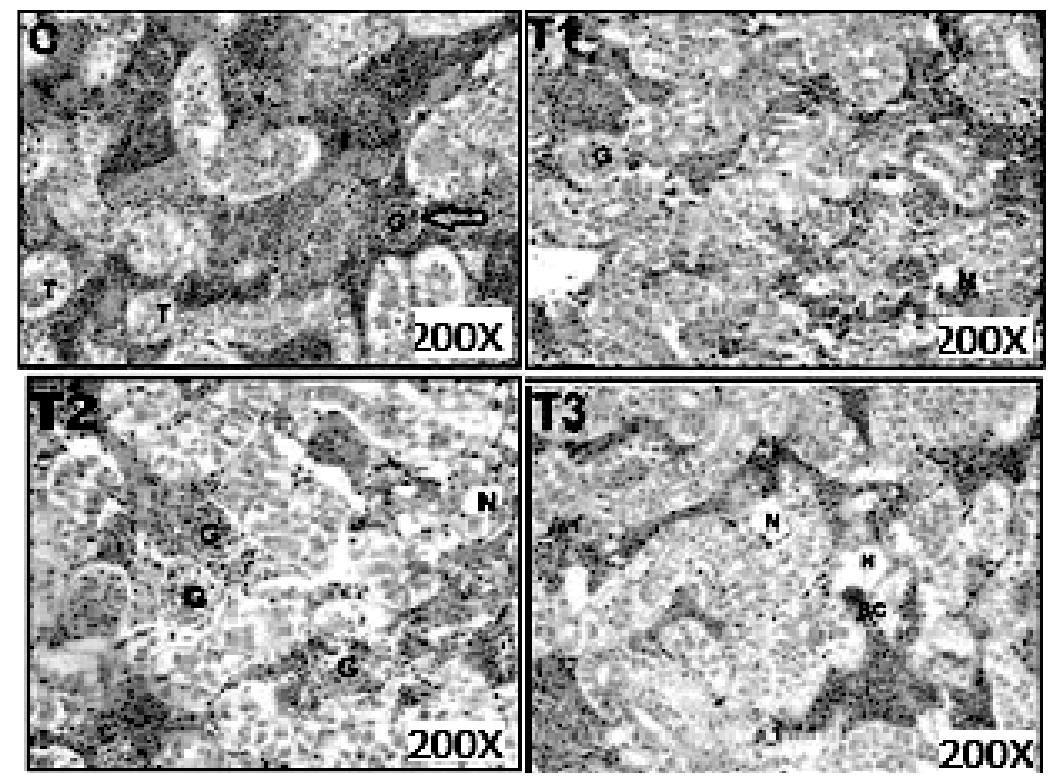

Figure 7 - Kidney tissue of C. gariepinus (C) Control, HandE 200X-Glamorous (G), Bowman space (white arrow), Tubule (T). (T1) Exposed to $6.1 \mathrm{mg}$, HandE 200X - Glamorous started to expand (G), Vacuolar necrosis (N). (T2), Exposed to $12.2 \mathrm{mg}$, HandE 200X Glamorous expand (G), Tubular Necrosis (N). (T3) Exposed to $24.4 \mathrm{mg}$, HandE 200XBlood congestion (BC), Tubular necrosis(N).

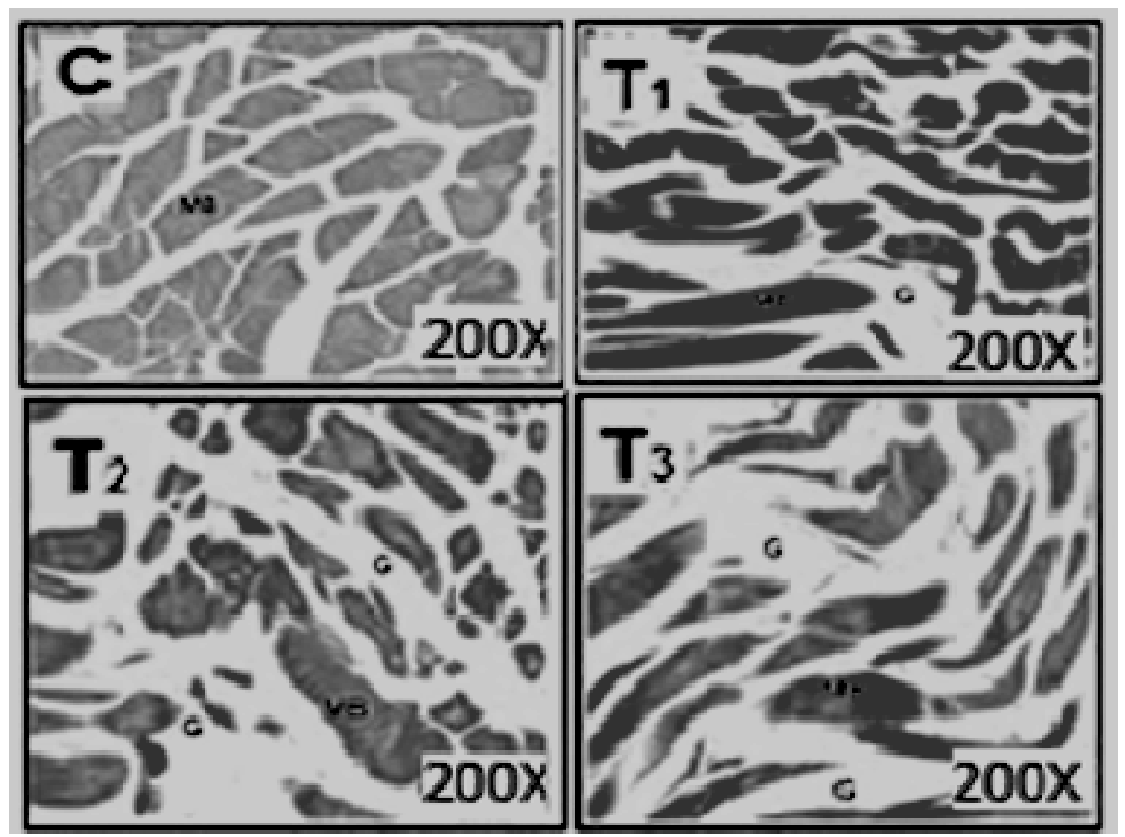

Figure 8 - Muscle tissue of C. gariepinus (C) Control, HandE 200X- Muscular bundles (MB). (M1) Exposed to $6.1 \mathrm{mg}$, HandE 200X- Gabs between muscular bundles (G). (M2) Exposed to $12.2 \mathrm{mg}$, HandE 200X - Muscular bundles (MB), Wider gapes between muscular bundles (G). (M3) Exposed to $24.4 \mathrm{mg}$, HandE 200X- Muscular bundles (MB), More expansion in gaps between muscular bundles $(\mathrm{G})$. 


\section{DISCUSSION}

Metals accumulation in fish tissues depends on the exposure concentration and time as well as other factors such as temperature, age, interaction with other metals, water chemistry and metabolic activity of the fish (Heath 1995). The present study showed that the lead was accumulated in the different organs of the fish. Figures 1-4 indicated the lead concentration in different organs of $C$. gariepinus. These results were higher than those reported by Seddek et al. (1996), Marouf and Dawoud (2006) and Kaoud and El-Dahshan (2010), whose recorded levels ranged from 0.42 to $1.52 \mathrm{ppm}$. This result was much higher than those recorded by Suppin et al. (2005) and Celik and Oehlenschlager (2007), whose recorded levels varied from $0.04 \mathrm{ppm}$ to $76.1 \mathrm{ppb}$. The distribution of heavy metals in all the fish organs studied were in the order of gills>liver >kidney>muscles. The highest concentration of lead $(597.7 \mu \mathrm{g} / \mathrm{g})$ was detected in the gill tissue of $C$. gariepinus, while the lowest was found in the muscle tissue (1.39 $\mu \mathrm{g} / \mathrm{g})$. These findings were in agreement Brooks and Rumsey (1974), Annune and Lyaniwura (1993) and Gbem et al. (2001) who studied the bioaccumulation of trace metals in several fishes species, including $C$. gariepinus. Oladimeji and Offem (1989) reported that in O. niloticus, the gills consistently accumulated higher amount of lead as lead nitrate. Crepso et al. (1981) found $\mathrm{Zn}$ to be highly accumulated in dog-fish gills. Okoye (1991) reported the level of accumulated $\mathrm{Pb}$ to be $2.28 \mu \mathrm{g} / \mathrm{g}$ fresh weights. Earlier studies in the Nigerian coastal waters reported $6.40 \mu \mathrm{g} / \mathrm{g}$ as maximum level of lead in finfish from the Warri area of Niger Delta (Kakulu and Osibanjo 1992). The high accumulation of lead in the gills tissues was probably due to the fact that the gills remained in direct contact of metal or it might be due to the fact that freshwater fish gills might be the primary route for the uptake of water borne pollutants (Allen and Wilson 1991). Similar findings were reported by Buhler et al. (1977) who found that highest concentrations were in the gills in rainbow trout. The gill is an important site for the entry of heavy metals that provokes lesions and gill damage (Bols et al. 2001). The present study found the liver to have accumulated metals significantly higher $(P<0.05)$ than kidney and muscular tissue. Beveridge et al. (1985) reported highest amounts of iron in haemoglobin- rich livers. Annune and Lyaniwura (1993) also reported the liver of $O$. niloticus and $C$. gariepinus to have accumulated $\mathrm{Zn}$ and $\mathrm{Cd}$ more than other tissues. The high accumulation of these metals in the liver could be related to the fact that the liver played an important role in accumulation and detoxification. Kidney is the gateway for heavy metal detoxification in the body (Vinodhini and Narayanan 2008). Present study showed that considerable amounts of heavy metals were accumulated in kidney tissues. Flesh is one of the ultimate parts for heavy metal accumulation. The heavy metals were uniformly spread over the body muscles. Hence, the observed values were relatively lower than the other potential organs. The presence of higher amounts of heavy metals in any parts of the body will definitely induce changes in biochemical metabolisms and other induced stresses. Studies on the accumulation of heavy metals in various organs of the fresh water fish exposed to sub-lethal concentrations were very much important. Also, the accumulation of lead in fish tissue increased with increasing lead concentration in water. There were significant differences in tissue concentrations among the treatment groups. The result of this study agreed with that of James et al. (1996) who observed that the fishes exposed to sub-lethal levels of lead produced dose-dependent significant increases in the concentration of lead in the liver and muscle of Oreochromis mossambicus.

Acute exposure to some chemicals can cause rapid destruction of gill lamellae within a few hours (Heath 1987). In fact, gills of $C$. gariepinus exposed to lead acetate for six weeks presented a higher occurrence of histopathological lesions such as epithelial lifting, hyperplasia and lamellar aneurism. Epithelial lifting and hyperplasia of the lamellar epithelium could be interpreted as defense responses of the fish, as these alterations increased the distance across which waterborne irritants must diffuse to reach the bloodstream (Mallat 1985). These changes in the gill epithelia were also observed in $P$. scrofa acutely exposed to copper (Mazon et al. 2002). Epithelial lifting and hyperplasia of undifferentiated epithelial cells are known to be nonspecific alterations, which can be caused by heavy metals (Randy et al. 1996). On the other hand, heavy metals were often associated with lamellar aneurism. Mallat (1985) suggested that pillar cells could be more resistant to metals than to most other kinds of irritants. However, the present study and the one by Mazon et al. (2002) showed that lead and copper, respectively, could 
cause lamellar aneurism in C. gariepinus and Prochilodus gills.

The liver showed degeneration of the hepatocytes, congestion of central vein and nuclear pyknosis in the majority of hepatic cells. These findings were apparent as the liver considered the organ of detoxification, excretion and binding proteins such as metallothionein (MTs). The metal-binding proteins were present in the nuclei of hepatocytes, which suggested that there was increase in the cell damages (DeSmet and Blust 2001). Similar results were observed by Van-Dyk (2003) and Mela et al. (2007). Liver of the fishes is sensitive to environmental contaminants because many contaminants tend to accumulate in the liver at much higher levels than in the other organs (Heath 1995). Pandey et al. (1994) described the alterations in the liver and intestine of Liza parsia exposed to $\mathrm{Hg} \mathrm{Cl}_{2}(0.2 \mathrm{mg} \mathrm{Hg} / \mathrm{l})$ for 15 days. Similarly, Oliveira- Ribeiro et al. (2002) reported serious injuries in the gills and olfactory epithelium of Salvelinus alpinus exposed to 0.15 $\mathrm{mg} \mathrm{Hg} / \mathrm{l}$. Although, according to Friberg et al. (1971), fishes are known to possess sequestering agent (metallothionein), the bioacumulation of these trace element in the liver tissue reaches a proportion in which the function of the liver is impeded, thus resulting in gradual degeneration of the liver cells syncytial arrangement. The surface area of the liver cell is also decreased, which may be due to the increase in the intrabiliary fibreconnective tissue. The intercellular spaces seen are zones of total cell degeneration. Thus, cirrhosis, the outcome of prolonged hepato-cellular injury is manifested by the fibrosis of hepatic cords and peribiliary connective tissue. Alterations in the muscles and kidney of Tilapia and in several other species of the fishes exposed to heavy metals have been described by Oliveira- Ribeiro et al. (2002), Jiraungkoorskul et al. (2003), Thophon et al. (2003), Gupta and Srivastava (2006) and Kaoud and El-Dahshan (2010), which were in line with the present investigation.

\section{CONCLUSION}

It could be concluded that the accumulation of lead in the fish was dependent on the exposure period and concentration. Gills and liver were predominant storage and most affected organs in the C. garipenus. Some structural changes specifically in the gills were observed under the stress of lead acetate. It is proposed that further investigation should be carried to investigate the extent of damage caused by lead acetate in the fish.

\section{ACKNOWLEDMENTS}

The project was supported by the Research Center, College of Science, King Saud University.

\section{REFERENCES - COLOCAR NAS NORMAS}

Abdallah GM, El-Sayed SM, Abo-Salem OM. Effect of lead toxicity on coenzyme Q levels in rat tissues. Food Chem Toxicol. 2010; 48: 1753 - 1756.

Allen GT and Wilson RM. Metals and organic compounds in fish of the Missouri River : Boyd County, Nebraska to Kansas City, Missouri. US FWS, Manhattan, Kansas 1991.

Annune PA and Lyaniwura TT. Accumulation of two trace metals in tissues of freshwater fishes, Oreochromis niloticus and Clarias gariepinus. $J$ Aquat Food Prod Technol. 1993; 2: 5-18.

Bergman HL and Dorward-King EJ. Reassessment of metals criteria for aquatic life protection. Pensacola: SETAC technical publication series, SETAC Press 1997.

Berrahal AA, Nehdi A, Hajjaji N, Gharbi N and ElFazaa S. Antioxidant enzymes activities and bilirubin level in adult rat treated with lead. C R Biol.2007; 330: 581-588.

Beveridge MC, Stafford E and Coutts R. Metal concentrations in the commercially exploited fishes of an endoheic saline lake in the tin silver province of Bolibvia. Aquacult Fish Management. 1985;1: 41-53.

Bols NC, Brubacher JL, Ganassin RC and Lee LEJ. Ecotoxicology and innate immunity in fish. Dev Comp Immunol. 2001; 25: 853-873.

Boyd SR. Heavy metal pollutants and chemical ecology: Exploring new frontiers. J Chem Ecol. 2010; 36: 46-58.

Brooks RA and Rumsey D. Heavy metals in some New Zealand commercial sea fishes. NZ J Mar Freshwater Res. 1974; 8: 155-166.

Buhler DR, Stokes RM and Coldwell SR. Tissue accumulation and enzymatic effects of hexavalent chromium in Rainbow Trout (Salmo gairdneri). $J$ Fish Res Board Can. 1977; 34: 9-18.

Cavas T. In vivo genotoxicity of mercury chloride and lead acetate: Micronuleus test on acridine orange stained fish cells. Food Chem Toxicol. 2007; 46: 151157. 
Celik $\mathrm{U}$ and Oehlenschlager D. High contents of $\mathrm{Cd}$, $\mathrm{Pb}, \mathrm{Zn}$ and $\mathrm{Cu}$ in popular fishery products sold in Turkish Supermarkets. Food Control. 2007; 18: 258261.

Crepso E, Sariano E, Sampera C and Balasch J. Zinc and copper excretory organs of the dog fish Scyliorhinus canicula and chloride cell response following treatment with zinc sulphate. Mar Biol. 1981; 65: 117-125.

Dallinger R, Prosi F, Segner $H$ and Back $H$. Contaminate food and uptake of heavy metals by fish: A review and a proposal for further research. Oecol. 1987; 3: 91-98.

DeSmet $\mathrm{H}$ and Blust R. Stress responses and changes in protein metabolism in carp (Cyprinus carpio L.) during cadmium exposure. Ecotoxicol Environ Safety. 2001; 48: 255-262.

Friberg L, Piscator M and Northberg G. Cadmium in the environment. Chemical Rubber G. Cleveland. 1971.

Gbem TT, Balogun JK, Lawal FA and Annune PA. Trace metal accumulation in Clarias gariepinus (Teugels) exposed to sub-lethal levels of tannery effluent. Sci Total Environ. 2001; 271: 1-9.

Gupta P and Srivastava N. Effects of sublethal concentrations of zinc on histological changes and bioaccumulation of zinc by kidney of fish, Channa punctatus (Bloch). J Environ Biol. 2006; 27: 211215.

Handy RD. Dietary exposure to toxic metals in fish. In: Taylor . EW, editor, Toxicology of aquatic pollution, New York: Cambridge University Press 1996; 29-60.

Heath AG. Water pollution and fish physiology. CRC Press, Boca Raton, Fl. 1987.

Heath AG. Water pollution and fish physiology. CRC Press, Boca Raton, Fl. 1995.

James R, Sampath K and Alagrathinam S. Effects of lead on respiratory enzyme activity, glycogen and blood sugar levels of the teleost Oreochromis mossambicus (Peters) during accumulation and depuration. Asian Fish Sci. 1996; 9: 87-100.

Jiraungkoorskul W, Uptham ES, Kruatrachue M, Sahaphong S, Vichasri-Grams S and Pokethitiyook P. Biochemical and histopathological effects of glyphosate herbicide on Nile tilapia (Oreochromis niloticus). Environ Toxicol. 2003; 18: 260-267.

Kakulu SE and Osibanjo O. Pollution Studies of Nigerian Rivers. Trace metal levels in surface waters of the Niger Delta. J Environ Stud. 1992; 41: 287292.

Kaoud HA and El-Dahshan AR. Bioaccumulation and histopathological alterations of the heavy metals in Oreochromis niloticus fish. Nat Sci. 2010; 8: 147156.

Larsson A, Haux C and Sjo “beck M. Fish physiology and metal pollution: Result and experiences from laboratory and field studies. Ecotoxicol Environ Safety. 1985;p9: 250-81.
Mallatt J. Fish gill structural changes induced by toxicants and other irritants: a statistical review. Can J Aquatic Sci. 1985; 42: 630-648.

Marouf HA and Dawoud AS. Evaluation of heavy metals content in freshwater crayfish in Damietta. $J$ Veter Med Assoc Egypt. 2006; 66: 217-225.

Mazon AF, Monteio EAS, Pinheiro GHD and Fernandes MN. Hematological and physiological changes induced by short-term exposure to copper in the freshwater fish, Prochilodus scrofa. Braz J Biol. 2002; 62: 621-631.

Mela MR, Ventura F, Carvalho DF, Pelletier CE and Ribeiro CA. Effects of dietary methylmercury on liver and kidney histology in the neotropical fish Hoplias malabaricus. Ecotoxicol Environ Safety. 2007; 68: 426 - 35.

Mobarak YM. Review of the developmental toxicity and teratogenicity of three environmental contaminants (cadmium, lead and mercury). Catrina. 2008; 3: 31-43.

Mobarak YMS and Sharaf MM. Lead acetate induced histopathological changes in the gills and digestive system of silver sailfin (Poecilia latipinna). Int J Zool Res. 2011; 7: 1-18.

Nordberg GF, Fowler BA, Nordberg M and Friberg L. Handbook on the Toxicology of Metals. ( $3^{\text {rd }}$ eds.), Academic press , Amesterdam, 2007; ISBN-10: 0123694132, pp: 1024.

Okoye BOC. Heavy metals and organisms in the Lagos lagoon. Int J Environ Stud. 1991; 37: 285- 292.

Oladimeji AA and Offem BO. Toxicity of lead to Clarias lazera, Oreochromis niloticus, Chironomus tantans and Benacus sp. Water Air soil Pollut. 1989; 44: 191-201.

Oliveira-Ribeiro CA, Belger L, Pelletiter E and Rouleau C. Histopathological evidence of inorganic mercury and methylmercury toxicity in the arctic charr (Salvelinus alpinus). Environ Res. 2002; 90: 217-225.

Pandey AK, Mohamed MP and George KC. Histopathological alterations in liver and intestine of Liza parsia (Hamilton-Buchanan) in response to mercury toxicity. J Adv Zool. 1994; 15: 18-24.

Park SK, Schwartz J, Weisskopf M, Sparrow D and Vokonas PS. Low-level lead exposure, metabolic syndrome and heart rate variability: The VA normative aging study. Environ Health Perspect. 2006; 114:1718-1724.

Randy AS, Monserrat JM, Rodriguez EM and Romano LA. Histpathological effects of cadmium on the gills of the freshwater fish Macropsobrycon uruguayanae Eigenmann (Pisces, Atherinidae). J Fish Diseases. 1996; 19: 311-322.

Reglero MM, Taggart MA, Monsalve-Gonzalez L and Mateo R. Heavy metal exposure in large game from a lead mining area: effects on oxidative stress and fatty acid composition in liver . Environ Pollut. 2009;157: 1388-1395. 
Seddek AS, Salem DA, El-Sawi NM and Zaky ZM. Cadmium, lead, nickel, copper, manganese and flourine levels in River Nile fish. Assiut Veter Med J Egypt. 1996; 35: 95-102.

Sivaprasad MM, Taggart MA, Monsalve-Gonzales L and Mateo R. Combined efficacies of lipoic acid and 2, 3 -dimercaptosuccinic acid against lead induced lipid peroxidation in rat liver. $J$ Nutr Biochem. 2004;15: 18-23.

Sorensen EM. Metal poisoning in fish. CRC press, Boca Rato 1991.

Suppin D, Zahlbruckner R, Krapfenbauer CC, Hassan I, Hauser $C$ and Smulders F. Mercury, lead and cadmium content of fresh and canned fish collected from Austrian retail operations. Ernahrung Nutr. 2005; 29:456-460.

Thophon S, Kruatrachue M, Upatham ES, Pokethitiyook P, Sahaphong S and Jaritkhuan S. Histopathological alterations of white seabass, Lates calcarifer, in acute and subchronic cadmium exposure. Environ Pollut. 2003; 121: 307-320.
Van Dyk JC. Histological changes in the liver of Oreochromis mossambicus (Cichlidae) after exposure to cadmium and zinc. (M Sc thesis) Rand Afrikaans University, South Africa 2003.

Vinodhini $\mathrm{R}$ and Narayanan M. Bioaccumulation of heavy metals in organs of fresh water fish Cyprinus carpio (Common carp). Int J Environ Sci Technol. 2008; 5: 179-182.

\author{
Received: April 20, 2011; \\ Revised: July 16, 2012; \\ Accepted: December 17, 2012.
}

